\title{
New and rare lichens and allied fungi from the Pskov Region, Russia
}

\author{
Nina B. Istomina ${ }^{1}$, Olga V. Likhacheva ${ }^{1 *}$, Irina S. Stepanchikova ${ }^{2,3}$, \\ Ekaterina S. Kuznetsova ${ }^{2,3}$, Dmitry E. Himelbrant ${ }^{2,3}$ \\ ${ }^{1}$ Department of Botany and Plant Ecology, Pskov State University, Lenin sq. 2, 180000 Pskov, Russia. \\ E-mails: pgpu.istomina@mail.ru, olga.lich@mail.ru \\ ${ }^{2}$ Department of Botany, St. Petersburg State University, Universitetskaya emb. 7-9, 199034 St. Petersburg, Russia. \\ E-mails: stepa_ir@mail.ru, igel_kuzn@mail.ru, d_brant@mail.ru \\ ${ }^{3}$ Laboratory of Lichenology and Bryology, Komarov Botanical Institute RAS, \\ Professor Popov St. 2, 197376 St. Petersburg, Russia \\ *corresponding author: olga.lich@mail.ru
}

\begin{abstract}
Forty-one species of lichens and two lichenicolous fungi are reported from the Pskov Region. Of them, thirty-nine species are new for the region, including Lempholemma dispansum - a rare species with scattered distribution, previously recorded only once in the European Russia in the $19^{\text {th }}$ century. The most important findings are confined to ancient limestone outcrops and old manor parks: these habitats are also promising for further investigations, taking in account high level of anthropogenic transformation of the Pskov Region.
\end{abstract}

Keywords: Flavoplaca polycarpa, Lempholemma dispansum, lichens of calcareous rocks, new records, old manors

\section{INTRODUCTION}

The Pskov Region lies within North-Western European Russia and borders on Leningrad and Novgorod regions, also two regions of the Central European Russia (Smolensk and Tver'), and three countries (Belarus, Estonia and Latvia). It is located in the northwest of the Eastern European Plain between $55^{\circ} 37^{\prime}-59^{\circ} 01^{\prime} \mathrm{N}(380 \mathrm{~km}$ from north to south) and $27^{\circ} 21^{\prime}-31^{\circ} 30^{\prime} \mathrm{E}(202$ $\mathrm{km}$ from west to east), and stretched out from the north-west to the south-east. Approximate area of the region is $55,300 \mathrm{~km}^{2}$. The region is located within the Eastern European Platform and was covered with ice during the last glacial period (Valdai glaciation), that determined modern orography, tectonic regime and geological structure of the territory. Predominant type of relief is the undulating plain with hills or groups of hills, however, flat slopes and lowlands also occur (Malyarevskiy, 1971). The territory of the region belongs to the Baltic Sea basin, and relative proximity to the Atlantic Ocean makes climate transitional from continental to marine (temperate-continental) with moderately warm and humid summers, but relatively mild winters with little frosts.

The great extent of the Pskov Region and its landscape heterogeneity create intraregional differences in climate and nature. The northern part of the region is located within the south- ern taiga, while the southern part - within the subzone of mixed coniferous-broadleaved forests (Malyarevskiy, 1971). The natural forest landscapes of the region have been heavily transformed due to long-term human activity. Nowadays forests occupy $38 \%$ of the area of the region (Fedorchuk et al., 2004), swamps cover $17 \%$, agricultural landscapes - 29\% (Ivanov et al., 1997), and the rest $16 \%$ are settlements. About $9 \%$ of the total area of the region is covered by protected areas (Protected..., 2017).

The lichen diversity of the Pskov Region has been studied since the beginning of the $20^{\text {th }}$ century (Savicz, 1909); brief review of previous lichenological investigations was recently published by Istomina and Likhacheva (2010). Nowadays the preliminary list of lichens and allied fungi known from the Pskov Region includes 303 species (Istomina \& Likhacheva, 2010, 2011, 2014a, b), 121 of them are known within the town of Pskov (Istomina \& Likhacheva, 2009). The aim of this work is to improve knowledge on lichen diversity of the Pskov Region.

\section{MATERIAL AND METHODS}

The material was collected from 16 localities (Table 1) in 8 administrative districts of the Pskov Region (Fig. 1) in 2001-2017. Lichen ma- 


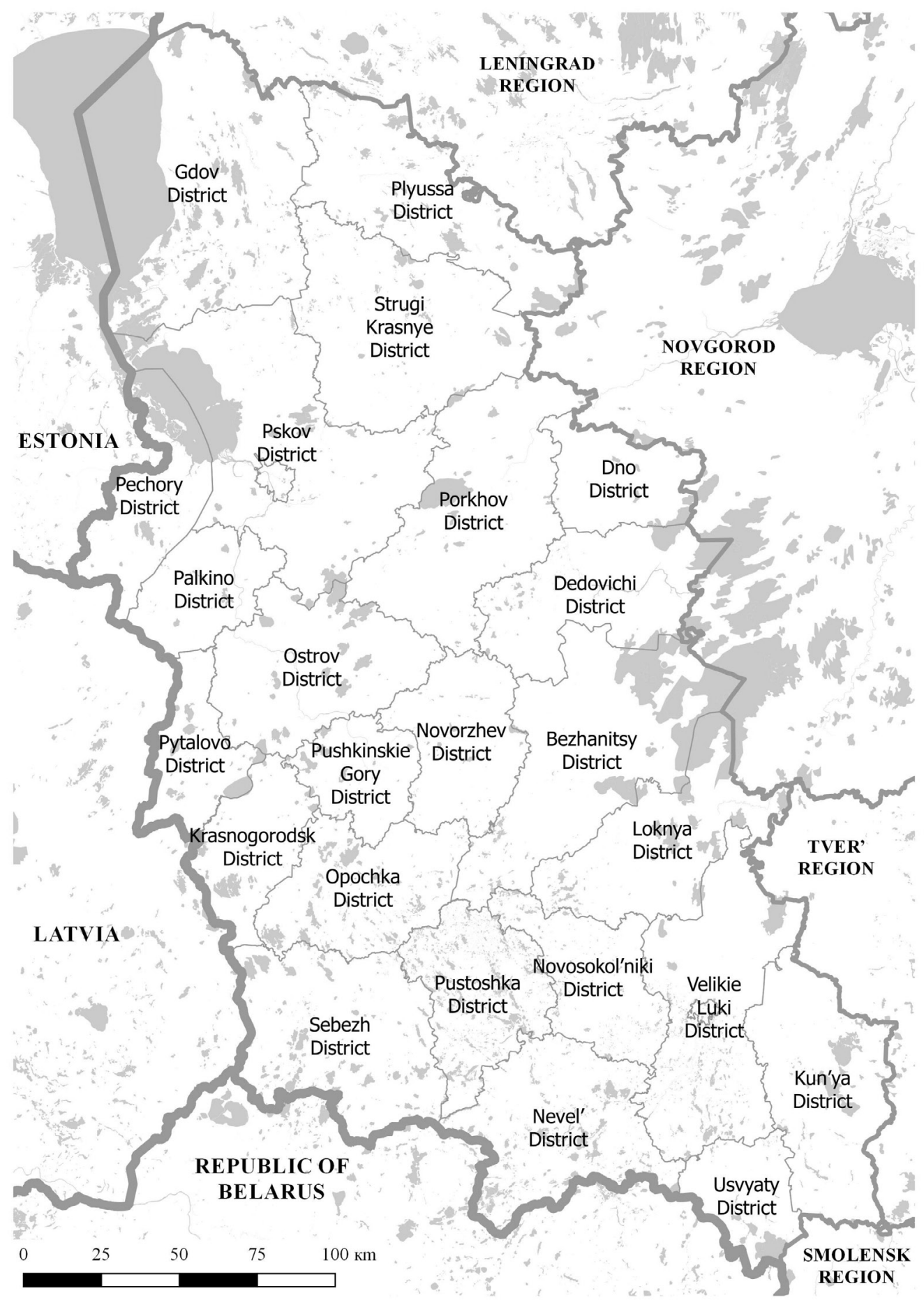

Fig. 1. Administrative division of the Pskov Region. 
Table 1. List of localities

No Locality, estimated geographical coordinates (WGS 1984)

Date and collectors (abbreviations)

1. Pechory District

1.1 Izborsk and vicinities, State Historical-Architectural, Landscape and Natural

2001, Tatiana V. Andreeva Museum-Preserve "Izborsk" and the Natural Monument "Izborsko-Mal'skaya dolina”, 5743'14.5”N 2751'25.6”E

2010, Nina B. Istomina \& Olga

V. Likhacheva (NI \& OL)

1.2 Pechory, Pskovskaya St., 5749'10.6”N 27³7’21.3”E

2007, Irina N. Dubskaya

1.3 Lavry village, $57^{\circ} 34^{\prime} 24.4^{\prime \prime} \mathrm{N} 27^{\circ} 28^{\prime} 32.4^{\prime \prime E}$

2005, NI \& OL

2. Gdov District

2.1 Vicinity of Pnevo village, International Ramsar territory "Pskovsko-Chudskaya priozernaya nizmennost”, State Nature Reserve “Remdovsky”, 58¹3'52.4”N

2003, NI $27^{\circ} 30^{\prime} 44.6$ ” E

2016, Anastasiya A. Kurka

2008, Ekaterina S. Yakovleva

2.2 Chernevo village, 5840'08”N 2714'28.1'E

3. Sebezh District, National Park "Sebezhsky»

3.1 Vicinity of Krasikovo village, 56 $06^{\circ} 26.8^{\prime \prime} \mathrm{N} 28^{\circ} 41^{\prime} 43.8^{\prime \prime} \mathrm{E}$

2010, OL

3.2 NW vicinity of Sosnovyy Bor, $56^{\circ} 16^{\prime} 10^{\prime \prime} \mathrm{N} 28^{\circ} 21^{\prime} 16^{\prime \prime} \mathrm{E}$

2017, Galina Yu. Konechnaya

4. Ostrov District

4.1 Vicinity of Gorai village, “Ostrovsky” protected area ('zakaznik'), 5707’39.8”N 2011, NI \& OL $28^{\circ} 30^{\prime} 48.1^{\prime \prime} \mathrm{E}$

5. Pushkinskie Gory District

5.1 Vicinity of Zagoski village, Natural Monument "Urochishche Zaozerye", $56^{\circ} 58^{\prime} 49.3$ ” N 2900’02.9”E

5.2 Pushkinskie Gory, State Museum-Reserve of A. S. Pushkin “Mikhailovskoye”, Petrovskoe manor, 5704'41"N 285' $55^{\prime \prime} \mathrm{E}$

5.3 Pushkinskie Gory, State Museum-Reserve of A. S. Pushkin “Mikhailovskoye”, 2009, EK ancient settlement Savkina Gorka, 5703'50”N 285' $18^{\circ}$ ”E

5.4 Pushkinskie Gory, State Museum-Reserve of A. S. Pushkin “Mikhailovskoye”, 2009, EK Trigorskoe manor, 5703'28”N 2852'02”E

6. Nevel' District

6.1 Vicinity of Krupevitsy village, $56^{\circ} 05^{\prime} 09.2^{\prime \prime} \mathrm{N} 30^{\circ} 05^{\prime} 37.3^{\prime \prime} \mathrm{E}$

2013, NI \& OL

7. Pskov

7.1 Zastennaya St., 5749'42.0”N, 28²0’04.2”E

7.2 Forest Park "Promezhitsy", 5745’38.0”N 28²2’22.6”E

2011, Mariya S. Radkevich

2011, NI \& OL

8. Pskov district

8.1 Vicinity of Krivsk village, Natural monument "Zapadnyy bereg Pskovskogo 2017, NI ozera", 5751'49.6”N 275' 56.7”'E

terial was identified by the authors of the paper; all mentioned specimens are deposited in the herbarium of Pskov State University (PSK). The nomenclature of taxa is given in accordance with Nordin et al. (2011). Species new to the Pskov Region are marked with *, lichenicolous fungiwith \#. All species in the list are accompanied by information on locality number and details, substrates, dates of collection, and herbarium numbers. Distribution in the regions and countries, bordering the Pskov Region, is discussed (abbreviations: Leningrad Region - LR, Novgorod Region - NR, Tver' Region - TR, Smolensk Re- gion - SR, Estonia - EST, Latvia - LAT, and Belarus - BEL). For species new to North-Western European Russia brief notes on distinguishing characteristics are added; indicator and specialized species of biologically valuable forests (Andersson et al., 2009) are commented.

\section{THE SPECIES}

*ABsconditella lignicola Vězda \& Pišút - 6.1: near the shore of Lake Vokshinskoe, pine forest, on decaying wood, 11.06.2013 (PSK 5850). Distribution in neighboring territories: LR (Kuznet- 
sova et al., 2007), NR (Kataeva, 2013), TR (Notov et al., 2011), EST (Randlane et al., 2016), LAT (Motiejūnaitè et al., 2006), BEL (Bely, 2012b).

*Acarospora fuscata (Schrad.) Th. Fr. - 2.1: shore of Lake Teploe, on granite boulder, 16.09.2016 (PSK 5880). Distribution in neighboring territories: LR (Kuznetsova et al., 2007), NR (Kataeva, 2002), TR (Notov et al., 2011), SR (Zhdanov, 2006), EST (Randlane et al., 2016), LAT (Ābolina et al., 2015), BEL (Yatsyna \& Merzhvinsky, 2012).

*Acarospora glaucocarpa (Ach.) Körb. - 1.1: Izborsk fortress, on limestone, 28.05.2010 (PSK 5882). Distribution in neighboring territories: LR (Stepanchikova et al., 2014), NR (Kataeva, 2002), TR (Notov et al., 2011), EST (Randlane et al., 2016).

*ANisomeridium POLYPORI (Ellis \& Everh.) M. E. Barr - 5.2: old manor park, on bark of old Tilia cordata L., 16.08.2009 (PSK 5915). Distribution in neighboring territories: LR (Kuznetsova et al., 2007), NR (Stepanchikova et al., 2013), TR (Notov et al., 2011), EST (Randlane et al., 2016), LAT (Motiejūnaitè et al., 2016), BEL (Yatsyna, 2014).

*ARthonia helvola (Nyl.) Nyl. - 5.2: old manor park, on bark of old Tilia cordata, 16.08.2009 (PSK 5918). Distribution in neighboring territories: LR (Kuznetsova et al., 2007), TR (Notov et al., 2011), EST (Randlane et al., 2016). Indicator species of old-growth forests and unique rocky habitats in biologically valuable forests in North-Western European Russia (Andersson et al., 2009).

*ARTHONia MEdiella Nyl. - 5.2: old manor park, on bark of old Tilia cordata, 16.08.2009 (PSK 5919). Distribution in neighboring territories: LR (Kuznetsova et al., 2007), TR (Notov et al., 2011), EST (Randlane et al., 2016).

*Bacidina sulphurella (Samp.) M. Hauck \& V. Wirth - 5.2: old manor park, on bark of old Quercus robur L., 20.08.2009 (PSK 5921). Distribution in neighboring territories: LR (Stepanchikova et al., 2017), EST (Randlane et al., 2016), BEL (Yatsyna, 2013b). Our specimen has well-developed finely granular thallus, apothecia with dark hypothecium, and white pycnidia containing hook-shaped conidia, typical for the species (Brand et al., 2009).

BAeOMYCES RUfus (Huds.) Rebent. - 7.2: pine forest, on sandy soil, 28.09.2011 (PSK 5846).
The first record for the town of Pskov and third record for the Pskov Region. Known from the Plyussa (Ganeshin, 1932) and Porkhov (vicinity of Vyachok village, 25.09.2004, S. Dmitrieva, NI, PSK 3691) districts. Distribution in neighboring territories: LR (Kuznetsova et al., 2007), NR (Kataeva, 2009), TR (Notov et al., 2011), EST (Randlane et al., 2016), LAT (Ābolina et al., 2015), BEL (Tsurykau \& Khramchenkova, 2011).

*Biatora efflorescens (Hedl.) Räsänen - 2.2: old manor park, on bark of Tilia cordata, 15.08.2008 (PSK 5847). Distribution in neighboring territories: LR (Kuznetsova et al., 2007), NR (Stepanchikova et al., 2013), TR (Notov et al., 2011), EST (Randlane et al., 2016), LAT (Āboliņa et al., 2015), BEL (Tsurykau, 2017).

*Bilimbia sabuletorum (Schreb.) Arnold - 1.1: Izborsk fortress, on bryophytes on limestone, among Lepraria incana (L.) Ach. and Lepraria sp., 28.05.2010 (PSK 5845). Distribution in neighboring territories: LR (Kuznetsova et al., 2007), NR (Kataeva, 2002), TR (Notov et al., 2011), SR (Golubkova, 1999), EST (Randlane et al., 2016), LAT (Ābolina et al., 2015), BEL (Yatsyna, 2013a).

${ }^{*}$ Caloplaca stillicidiorum (Vahl) Lynge s. lat. (sensu Šoun et al., 2011 - see discussion on pp. 129-130) - 1.1: vicinity of Izborsk, slope of Izborsk-Maly ancient valley near Smolka River, limestone outcrops, on plant debris on limestone, 09.07.2001 (PSK 5903). Distribution in neighboring territories: EST (Randlane et al., 2016). Differs from closely related Caloplaca cerina (Hedw.) Th. Fr. by thick, grey, pruinose thalline margin and plane, sordid green to sordid yellowish-green, pruinose disk of apothecia as well as preference to plant debris on calcareous substrates (Fletcher \& Laundon, 2009; Šoun et al., 2011).

${ }^{*}$ Candelariella lutella (Vain.) Räsänen - 5.4: aspen grove, on bark of Populus tremula L., 19.08.2009 (PSK 5922). Distribution in neighboring territories: LR (Kuznetsova et al., 2007), NR (Tagirdzhanova et al., 2014), TR (Notov et al., 2011), EST (Randlane et al., 2016).

${ }^{*}$ Circinaria contorta (Hoffm.) A. Nordin et al. subsp. CONTORTA - 1.1: vicinity of Izborsk, slope of Izborsk-Maly ancient valley, limestone outcrops, on limestone, 07.06.2010 (PSK 5836). Distribution in neighboring territories: LR (Stepanchikova et al., 2017), TR (Notov et al., 2011), 
EST (Randlane et al., 2016), LAT (Ābolinga et al., 2015), BEL (Yatsyna \& Merzhvinsky, 2012).

*Cladonia Pocillum (Ach.) Grognot - 1.1: vicinity of Izborsk, near the river Smolka, limestone outcrop, on fine-grained soil among bryophytes, 09.06.2001 (PSK 5863); Izborsk, $100 \mathrm{~m}$ from the Nativity church, limestone outcrops, on finegrained soil among bryophytes, 28.05.2010 (PSK 5864). Distribution in neighboring territories: LR (Kuznetsova et al., 2007), TR (Notov et al., 2011), EST (Randlane et al., 2016), LAT (Ābolina et al., 2015), BEL (Yatsyna \& Merzhvinsky, 2012).

*Cladonia Symphycarpa (Flörke) Fr. -1.1 : vicinity of Izborsk, slope of Izborsk-Maly ancient valley near Lake Gorodishchenskoe, on limestone outcrops, on fine-grained soil among bryophytes, 09.07.2001 (PSK 5878). Distribution in neighboring territories: LR (Alexeeva \& Himelbrant, 2007), TR (Notov et al., 2011), EST (Randlane et al., 2016), LAT (Āboliņa et al., 2015).

*\#Clypeococcum hypocenomycis D. Hawksw. 5.1: pine forest, on thallus of Hypocenomyce scalaris (Ach.) M. Choisy on bark of Pinus sylvestris L., 17.06.2015 (PSK 5857). Distribution in neighboring territories: LR (Kuznetsova et al., 2007), NR (Stepanchikova et al., 2013), TR (Notov et al., 2011), EST (Randlane et al., 2016), LAT (Moisejevs, 2017), BEL (Tsurykau \& Khramchenkova, 2011).

DiBAEIS BAEOMYCES (L. fil.) Rambold \& Hertel 3.2: pine forest, clearing for power line, on soil, 21.10.2017 (PSK 5886); 8.1: edge of pine forest, on sandy soil, 05.09.2017 (PSK 5902). This species previously was known from the Nevel' District (Istomina, Likhacheva, 2014a). Distribution in neighboring territories: LR (Kuznetsova et al., 2007), NR (Kataeva, 2002), TR (Notov et al., 2011), EST (Randlane et al., 2016), LAT (Āboliņa et al., 2015), BEL (Tsurykau \& Khramchenkova, 2011).

*Diploschistes muscorum (Scop.) R. Sant. - 1.1: vicinity of Izborsk, slope of Izborsk-Maly ancient valley, limestone outcrops, on thallus of Cladonia pyxidata (L.) Hoffm., 09.07.2001 (PSK 5858). Distribution in neighboring territories: LR (Himelbrant et al., 2015), TR (Notov et al., 2011), EST (Randlane et al., 2016), LAT (Āboliņa et al., 2015), BEL (Tsurykau, 2017).

*Enchylium tenax (Sw.) Gray - 7.1: medieval walls of Pskov citadel, on limestone, 26.08.2011 (PSK
5833). Distribution in neighboring territories: LR (Kuznetsova et al., 2016), TR (Notov et al., 2011), EST (Randlane et al., 2016), LAT (Ābolina et al., 2015), BEL (Yatsyna \& Merzhvinsky, 2012).

*Flavoplaca polycarpa (A. Massal.) Arup et al. (Fig. 2) - 1.1: Izborsk fortress, fortress walls, on thallus of Verrucaria sp. on limestone, 28.05.2010 (PSK 5904). Distribution in neighboring territories: not reported. In Russia previously known from Dagestan (Urbanavichus et al., 2011) and Central European Russia (Muchnik et al., 2014). Characterized by thin, indistinctly rosette-like areolate yellow-orange thallus, sessile orange to orange-red apothecia, ellipsoid spores with wide septum (more than $3 \mu \mathrm{m})$ and parasitizing on verrucarioid lichens (Wilk, 2012; Wirth et al., 2013).

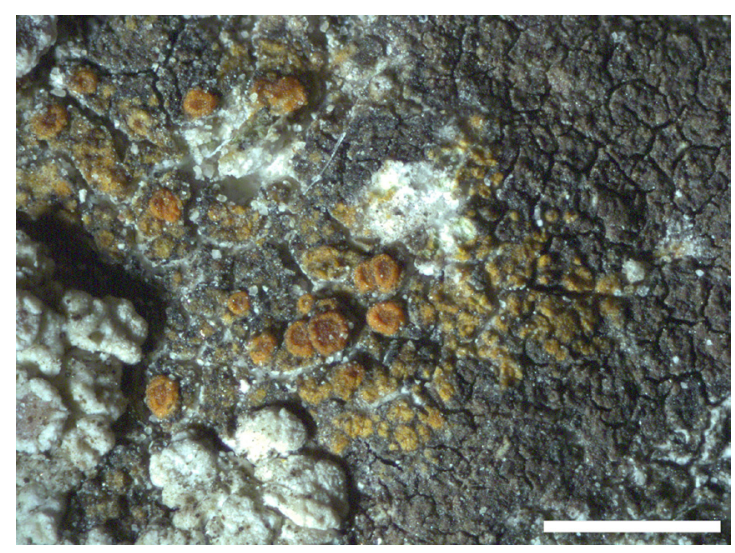

Fig. 2. Thallus of Flavoplaca polycarpa on Verrucaria sp. (PSK 5904). Scale bar $=1 \mathrm{~mm}$.

*Hypogymnia Farinacea Zopf - 5.3: solitary pines on the slope of hill, on bark of Pinus sylvestris, 17.08.2009 (PSK 5923). Distribution in neighboring territories: LR (Alexeeva \& Himelbrant, 2007), TR (Notov et al., 2011), EST (Randlane et al., 2016), LAT (Ābolina et al., 2015), BEL (Yatsyna \& Merzhvinsky, 2012).

*Inoderma byssaceum (Weigel) Gray - 5.2: old manor park, on bark of old Tilia cordata, 16.08.2009 (PSK 5916); 5.4: old manor park, on bark of Fraxinus excelsior L., 19.08.2009 (PSK 5917). Distribution in neighboring territories: LR (Stepanchikova et al., 2011b), TR (Notov et al., 2011), EST (Randlane et al., 2016), LAT (Ābolinia et al., 2015), BEL (Yatsyna \& Merzhvinsky, 2012). Specialized species of old-growth 
black alder and broadleaved mixed forests in North-Western European Russia (Andersson et al., 2009).

*LATHAGRIUm FuscoviRens (With.) Otálora et al. - 1.1: Izborsk, rampart of Truvor ancient settlement, on limestone outcrops, 28.05.2010 (PSK 5831). Distribution in neighboring territories: LR (Kuznetsova et al., 2016), EST (Randlane et al., 2016), LAT (Ābolina et al., 2015), BEL (Yatsyna $\&$ Merzhvinsky, 2012).

LECANORA EXPALLENS Ach. - 1.3: old manor park, on decaying tree trunk, 22.10.2005 (PSK 2502). The species was mentioned by Nedospasova (1983), but record is not confirmed by the herbarium specimens. Distribution in neighboring territories: LR (Stepanchikova et al., 2011a), EST (Randlane et al., 2016), LAT (Āboliña et al., 2015), BEL (Tsurykau \& Khramchenkova, 2011).

*LeCANORA hyPOPTElla (Nyl.) Grummann - 6.1: shore of Lake Vokshinskoe, pine forest, on bark of Pinus sylvestris, 12.06.2013 (PSK 5874). Distribution in neighboring territories: LR (Stepanchikova et al., 2011a), TR (Notov et al., 2016).

*LECANORA INTRICATA (Ach.) Ach. - 2.1: shore of Lake Teploe, on granite boulder, 16.09.2016 (PSK 5881). Distribution in neighboring territories: LR (Kuznetsova et al., 2007), TR (Notov et al., 2011), EST (Randlane et al., 2016), LAT (Ābolina et al., 2015), BEL (Yatsyna \& Merzhvinsky, 2012).

*Lecidea Nylanderi (Anzi) Th. Fr. - 3.1: bank of Nishcha River, edge of pine forest, on bark of Juniperus communis L., 16.09.2010 (PSK 5835). Distribution in neighboring territories: LR (Kuznetsova et al., 2007), NR (Stepanchikova et al., 2013), TR (Notov et al., 2011), EST (Randlane et al., 2016), LAT (Motiejūnaitè et al., 2006), BEL (Yatsyna \& Merzhvinsky, 2012).

*Lecidella stigmatea (Ach.) Hertel \& Leuckert 1.1: Izborsk, rampart of Truvor ancient settlement, on limestone outcrops, 28.05.2010 (PSK 5831). Distribution in neighboring territories: LR (Kuznetsova et al., 2007), NR (Kataeva, 2002), TR (Notov et al., 2011), SR (Zhdanov, 2006), EST (Randlane et al., 2016), LAT (Āboliña et al., 2015), BEL (Yatsyna \& Merzhvinsky, 2012).

*Lempholemma dispansum H. Magn. (Fig. 3) 7.1: medieval walls of Pskov citadel, on lime- stone, 26.08.2011 (PSK 5832). Distribution in neighboring territories: not reported. In North-Western European Russia known from Republic of Karelia on the base of specimen from $\mathrm{H}$ (sine num.), collected by J. P. Norrlin in 1870 (Fadeeva et al., 2007). In Russia also known form Krasnoyarsk Kray (Zdanov, 2012), in Northern Europe - from Sweden, southern Norway, northern Germany (Jørgensen, 2007) and from Finland (Pykälä, 2010). Rather distinct species, characterized by thallus, consisting of dense imbricate flattened sterile squamules up to $5 \mathrm{~mm}$ wide (Jørgensen, 2007).

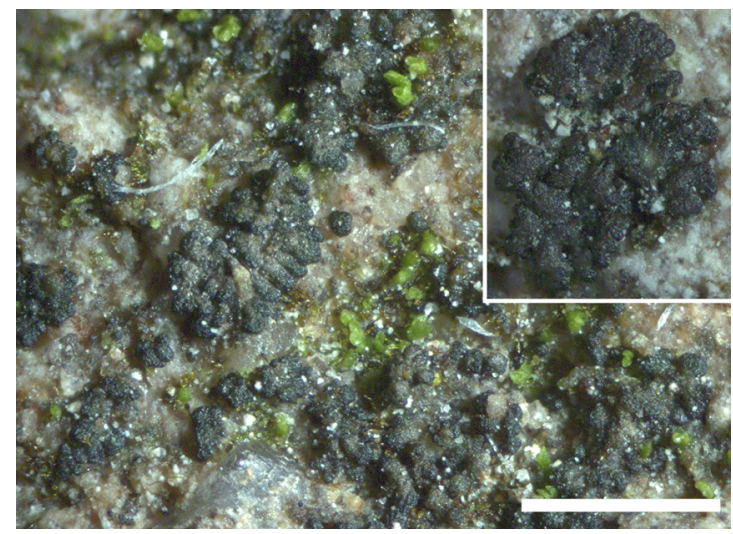

Fig. 3. Thallus of Lempholemma dispansum (PSK 5832). Scale bar $=1 \mathrm{~mm}$.

*\#Muellerella hospitans Stizenb. - 5.4: old manor park, on apothecia of Bacidia rubella (Hoffm.) A. Massal. on bark of Acer platanoides L., 19.08.2009 (PSK 5924). Distribution in neighboring territories: LR (Himelbrant et al., 2013), EST (Randlane et al., 2016), LAT (Āboliņa et al., 2015), BEL (Yatsyna, 2016).

*Myriolecis albescens (Hoffm.) Śliwa et al. - 1.1: Izborsk fortress, on limestone of fortress walls, 28.05.2010 (PSK 5834). Distribution in neighboring territories: LR (Kuznetsova et al., 2007), TR (Notov et al., 2011), EST (Randlane et al., 2016), LAT (Āboliņa et al., 2015).

Peltigera neckeri Hepp ex Müll. Arg. - 1.2: cemetery, on soil, 20.10.2007 (PSK 5851). Second record for the region (Istomina \& Likhacheva, 2010). Distribution in neighboring territories: LR (Kuznetsova et al., 2007), NR (Kataeva, 2002), TR (Notov et al., 2011), EST (Randlane et al., 2016), LAT (Āboliņa et al., 2015), BEL (Bely, 2012a). 
*Peltigera neopolydactyla (Gyeln.) Gyeln. - 4.1: mixed forest, on bark of fallen trunk of Populus tremula, 22.07.2011 (PSK 5877). Distribution in neighboring territories: LR (Kuznetsova et al., 2007), TR (Notov et al., 2011), EST (Randlane et al., 2016), LAT (Ābolinga et al., 2015), BEL (Bely, 2012a).

*Phaeophyscia endophoenicea (Harm.) Moberg - 5.2: old manor park, on bark of old Fraxinus excelsior, 20.08.2009 (PSK 5925). Distribution in neighboring territories: LR (Stepanchikova et al., 2009), EST (Randlane et al., 2016), LAT (Motiejūnaitè et al., 2016).

*Placynthiella dasaea (Stirt.) Tønsberg - 3.1: bank of Nishcha River, edge of pine forest, on decaying tree trunk, 16.09.2010 (PSK 5285). Distribution in neighboring territories: LR (Kuznetsova et al., 2007), NR (Kataeva, 2009), TR (Notov et al., 2011), EST (Randlane et al., 2016), LAT (Motiejūnaitė et al., 2006).

*Placynthiella oligotropha (J. R. Laundon) Coppins \& P. James - 6.1: shore of Lake Vokshinskoe, pine forest, on plant debris, 11.06.2013 (PSK 5856). Distribution in neighboring territories: LR (Kuznetsova et al., 2007), TR (Notov et al., 2011), EST (Randlane et al., 2016).

*Placynthium nigrum (Huds.) Gray - 1.1: Izborsk, rampart of Truvor ancient settlement, limestone outcrops, on limestone, 28.05.2010 (PSK 5831). Distribution in neighboring territories: LR (Kuznetsova et al., 2007), NR (Kataeva, 2002), TR (Notov et al., 2011), EST (Randlane et al., 2016), LAT (Āboliņa et al., 2015), BEL (Golubkov, 2013).

*Protoblastenia RUPestris (Scop.) J. Steiner 1.1: vicinity of Izborsk, slope of Izborsk-Maly ancient valley, limestone outcrops, on limestone, 19.05.2010 (PSK 5837). Distribution in neighboring territories: LR (Kuznetsova et al., 2016), TR (Notov et al., 2011), EST (Randlane et al., 2016), LAT (Ābolina et al., 2015), BEL (Yatsyna $\&$ Merzhvinsky, 2012).

*Psoroglaena dictyospora (Orange) H. Harada - 5.2: shore of Lake Kuchane, between Mikhailovskoe and Petrovskoe manors, bark of Ulmus sp., 20.08.2009 (PSK 5926). Distribution in neighboring territories: LR (Himelbrant et al., 2015), TR (Notov et al., 2011), EST (Randlane et al., 2016).

*RhizocaRpon Distinctum Th. Fr. -2.1 : shore of Lake Teploe, on granite boulder, 16.09.2016
(PSK 5880, 5881). Distribution in neighboring territories: LR (Kuznetsova et al., 2007), TR (Notov et al., 2011), EST (Randlane et al., 2016), LAT (Āboliņa et al., 2015), BEL (Yatsyna \& Merzhvinsky, 2012).

*SCytinium lichenoides (L.) Otálora et al. - 1.1: vicinity of Izborsk, slope of Izborsk-Maly ancient valley near Lake Gorodishchenskoe, limestone outcrops, on fine-grained soil among bryophytes, 06.07.2001 (PSK 5859). Distribution in neighboring territories: LR (Kuznetsova et al., 2007), TR (Notov et al., 2011), EST (Randlane et al., 2016), LAT (Ābolina et al., 2015), BEL (Yatsyna \& Merzhvinsky, 2012). Indicator species of old-growth forests and unique rocky habitats in biologically valuable forests in North-Western European Russia (Andersson et al., 2009).

*Stereocaulon condensatum Hoffm. - 2.1: shore of Lake Teploe, dunes, on sand, 03.06.2003 (PSK 5873). Distribution in neighboring territories: LR (Kuznetsova et al., 2007), NR (Kataeva, 2002), TR (Notov et al., 2011), EST (Randlane et al., 2016), LAT (Āboliņa et al., 2015), BEL (Tsurykau \& Khramchenkova, 2011).

*STRANGOSPORA MORIFORMis (Ach.) Stein. - 5.2: sandy spit between Lake Kuchane and Sorot' River, oak-pine forest, on bark of Pinus sylvestris, 15.08.2009 (PSK 5927); 5.3: solitary pines on the slope of hill, on bark of Pinus sylvestris, 17.08.2009 (PSK 5928). Distribution in neighboring territories: LR (Kuznetsova et al., 2007), NR (Kataeva, 2009), TR (Notov et al., 2011), SR (Golubkova, 1966), EST (Randlane et al., 2016), LAT (Āboliņa et al., 2015), BEL (Yatsyna \& Merzhvinsky, 2012).

\section{DISCUSSION}

Altogether 41 species of lichens and two lichenicolous fungi are published here, 39 of them are new for the Pskov Region, three (Baeomyces rufus, Enchylium tenax, and Lempholemma dispansum) - for the town of Pskov. Most of the species are more or less common and widely distributed in neighboring countries and regions (data lacking for underinvestigated neighboring Smolensk Region). However, some species represent a special interest. Lempholemma dispansum is a rare sterile species with scattered distribution (Jørgensen, 2007). It was known previously in North-Western European Russia from Republic of Karelia on the base of specimen collected in 
the $19^{\text {th }}$ century (Fadeeva et al., 2007). The species is also known from East Siberia (Zdanov, 2012) and our sample is the third record for Russia. Lichenicolous lichen Flavoplaca polycarpa was previously known from the Central European Russia, but is published here as new to the North-Western European Russia.

The significant and noteworthy part of lichens reported here is a group of species inhabiting calcareous substrates. Nine species (Acarospora glaucocarpa, Circinaria contorta subsp. contorta, Enchylium tenax, Lathagrium fuscovirens, Lecidella stigmatea, Lempholemma dispansum, Myriolecis albescens, Placynthium nigrum, and Protoblastenia rupestris) grow directly on limestone outcrops of the Izborsk-Maly valley, or on limestone walls of Izborsk and Pskov fortresses. Other seven lichens (Bilimbia sabuletorum, Caloplaca stillicidiorum, Cladonia pocillum, C. symphycarpa, Diploschistes muscorum, Flavoplaca polycarpa, and Scytinium lichenoides) inhabit plant debris, mosses, lichen thalli, and calcareous soil covering limestones.

Only a few of listed species - Arthonia helvola, Inoderma byssaceum, and Scytinium lichenoides - are known indicators of biologically valuable old-growth forests, old parks or unique rocky habitats in North-Western European Russia (Andersson et al., 2009). Two of them were collected in old manor parks, and one species - in ancient calcareous valley near the lake.

The significant long-term anthropogenic transformation of landscapes and nature of the Pskov Region influences the lichen diversity: most of species mentioned here can survive in secondary and fragmented forests, parks or even settlements. Many of them are known nowadays within St. Petersburg: for example, epiphytes Anisomeridium polypori, Arthonia mediella, $\mathrm{Ba}$ cidina sulphurella, Biatora efflorescens, Candelariella lutella, Hypogymnia farinacea, Lecanora expallens, Lecidea nylanderi, Phaeophyscia endophoenicea, Psoroglaena dictyospora, and Strangospora moriformis, as well as saxicolous lichens Acarospora fuscata, Lecanora intricata, and Rhizocarpon distinctum (see Himelbrant et al., 2006; Stepanchikova et al., 2008, 2010).

Our results suggest that most interesting data on regional lichen diversity can be obtained during further investigations in areas with ancient limestone outcrops and old manor parks; the majority of other types of habitats are anthropogenic or secondary, therefore they provide suitable conditions for common and widespread species mostly. Further special studies of lichenicolous fungi are expected, as nowadays only four species of this group are known from the Pskov Region (Istomina \& Likhacheva, 2010; this article).

\section{ACKNOWLEDGEMENTS}

Two first authors are grateful to Pskov State University graduates Mariya S. Radkevich, Ekaterina S. Yakovleva, Irina N. Dubskaya, Tatiana V. Andreeva, and MSc student Anastasiya A. Kurka for assistance in field investigations. Olga Likhacheva is also sincerely thankful to Dr Sergey A. Fetisov (Sebezh) for great help during the field trips in National Park "Sebezhsky". Ekaterina Kuznetsova would like to thank Dr Boris K. Gannibal for organization of the expedition to State Museum-Reserve of A. S. Pushkin "Mikhailovskoye" and permanent support. We express our gratitude to Dr Galina Yu. Konechnaya (St. Petersburg) for providing specimen from National Park "Sebezhsky" and senior lecturer Sergey G. Mikhalap (Pskov) for help and useful comments in map preparation. We are grateful to anonymous reviewer and Tiina Randlane for valuable corrections and comments. The work of Irina Stepanchikova, Ekaterina Kuznetsova and Dmitry Himelbrant was carried out within the framework of the institutional research project (no. 0126-20180006) of the Komarov Botanical Institute of the Russian Academy of Sciences.

\section{REFERENCES}

Ābolina, A., Piterāns, A. \& Bambe, B. 2015. Lichens and bryophytes in Latvia. Checklist. (In Latvian, English introductions). Daugavpils, Daugavpils Universitātes Akadēmiskais apgāds "Saule». 213 pp.

Alexeeva, N. M. \& Himelbrant, D. E. 2007. Lichens. In: Tzvelev, N. N. (executive ed.). Environment and biological diversity of Berezovye Islands Archipelago (The Gulf of Finland). (In Russian, English summary). St. Petersburg. Pp. 213-229.

Andersson, L., Alexeeva, N. M. \& Kuznetsova, E. S. (eds). 2009. Survey of biologically valuable forests in North-Western European Russia. Vol. 2. Identification manual of species to be used during survey at stand level. (In Russian). St. Petersburg. $258 \mathrm{pp}$.

Bely, P. 2012a. Geographical structure of the lichen flora of spruce forests in Belarus. (In Russian). 
Bulletin of the I. P. Shamyakin Mozyr State Pedagogical University 1(34): 3-10.

Bely, P. 2012b. Absconditella lignicola (Stictidaceae) - lichen species new to Belarus. Botanica Lithuanica 18(2): 164-165. https://doi.org/10.2478/ v10279-012-0018-2

Brand, M., Coppins, B. J., van den Boom, P. P. G. \& Sérusiaux, E. 2009. Further data on the lichen genus Bacidia s. 1. in the Canary Islands and Western Europe, with descriptions of two new species. Bibliotheca Lichenologica 99: 81-92.

Fadeeva, M. A., Golubkova, N. S., Vitikainen, O. \& Ahti, T. 2007. Conspectus of lichens and lichenicolous fungi of the Republic of Karelia (In Russian, English summary). Petrozavodsk. 194 pp.

Fedorchuk, V. N., Neshatayev, V. Yu. \& Kuznetsova, M. L. 2005. Forest Ecosystems of the North-Western regions of Russia: Typology, dynamics, forest management features. Saint-Petersburg. 382 p.

Fletcher, A. \& Laundon, J. R. 2009. Caloplaca Th. Fr. In: Smith, C. W., Aptroot, A., Coppins, B. J., Fletcher, A., Gilbert, O. L., James, P. W. \& Wolseley, P. A. (eds), The Lichens of Great Britain and Ireland. London, British Lichen Society. Pp. 245-273.

Ganeshin, S. S. 1932. Vegetation of the Lyady District of the Luga Okrug in connection with haematuria disease of cows. (In Russian). Proceedings of the Botanical Museum of the Academy of Sciences of the USSR 25: 349-434.

Golubkov, V. V. 2013. New records of rare and protected species from Belarus. Modern problems in botanical and mycological research. Proceedings of the second international conference, Minsk, November 12-14, 2013. (In Russian). Minsk. Pp. 188-190.

Golubkova, N. S. 1966. The handbook of lichens of the Middle European Russia. (In Russian). MoskowLeningrad. $256 \mathrm{pp}$.

Golubkova, N. S. 1999. Species of Mycobilimbia Rehm in the lichen flora of Russia. (In Russian). Novitates Systematicae Plantarum Non Vascularium 33: 107-114.

Himelbrant, D. E., Motiejūnaitė, J., Pykälä, J., Schiefelbein, U. \& Stepanchikova, I. S. 2013. New records of lichens and allied fungi from the Leningrad Region, Russia. IV. Folia Cryptogamica Estonica 50: 23-31. https://doi.org/10.12697/fce.2013.50.04

Himelbrant, D. E., Stepanchikova, I. S. \& Konoreva, L. A. 2006. Lichen flora of the Sergievka Park and its peculiarities. In: Monitoring of nature of the Sergievka Park. (In Russian). Transactions of the Biological Institute of Saint Petersburg State University 52: 58-89.

Himelbrant, D. E., Stepanchikova, I. S., Motiejūnaitè, J., Vondrak, J., Tagirdzhanova, G. M., Gagarina, L. V. \& Kuznetsova, E. S. 2015. New records of lichens and allied fungi from the Leningrad Region, Russia. VI. Folia Cryptogamica Estonica 52: 21-28. https:/ / doi.org/ 10.12697/fce.2015.52.03
Istomina, N. B. \& Likhacheva, O. V. 2009. Lichens. In: Environmental monitoring of the urban area with the bioindication methods (on the example of Pskov city). Part 1. (In Russian). Pskov. Pp. 81-95.

Istomina, N. B. \& Likhacheva, O. V. 2010. The preliminary list of lichens of the Pskov Region (Russia). (In Russian, English summary). Novitates Systematicae Plantarum Non Vascularium 44: 171-199.

Istomina, N. B. \& Likhacheva, O. V. 2011. To the study of lichens of the National Park "Sebezhsky". In: Proceedings of National Park "Sebezhsky". Part 1. (In Russian). Sebezh. Pp. 165-169.

Istomina, N. B. \& Likhacheva, O. V. 2014a. A new species of lichens for the Pskov Region. (In Russian, English summary). Bulletin of the Pskov State University. Series "Natural, physical and mathematical sciences" 4: 15-16.

Istomina, N. B. \& Likhacheva, O. V. 2014b. Lichens of National Park "Sebezhsky". In: Proceedings of the second international conference "Lichenology in Russia: problems and perspectives", St. Petersburg, November 5-8, 2014. (In Russian, English summary). St. Petersburg. Pp. 93-99.

Ivanov, I. A., Spasov, V. P. \& Ivanov, A. I. 1997. Soils of Pskov Region and their agricultural use. (In Russian). Velikie Luki. 263 pp.

Jørgensen, P. M. 2007. Lichinaceae. In: Nordic lichen flora. Vol. 3. Uddevalla. Pp. 46-76.

Kataeva (Katenina), O. A. 2002. Annotated list of lichens of the Novgorod Region. (In Russian, English summary). Novitates Systematicae Plantarum Non Vascularium 36: 114-143.

Kataeva, O. A. 2009. Lichens and lichenized fungi. In: Flora inventory of the Novgorod Region. (In Russian). Veliky Novgorod. Pp. 247-253.

Kataeva, O. A. 2013. To the lichen studies in Rdejsky Reserve. In: Proceedings of Rdejsky State Natural Reserve. Issue 2. (In Russian). Veliky Novgorod. Pp. 4-17.

Kuznetsova, E., Ahti, T. \& Himelbrant, D. 2007. Lichens and allied fungi of the Eastern Leningrad Region. Norrlinia 16: 1-62.

Kuznetsova, E. S., Kataeva, O. A., Himelbrant, D. E. \& Motiejūnaitè, J. 2016. Lichens and allied fungi of the Ragusha River Protected Area (Leningrad Region, Russia). Folia Cryptogamica Estonica 53: 71-80. https:/ /doi.org/ 10.12697 / fce.2016.53.09

Malyarevskiy, V. K. (Ed.) 1971. Nature of the Pskov Region districts. (In Russian). Pskov. 406 pp.

Moisejevs, R. 2017. Lichens and allied fungi new for Latvia. Folia Cryptogamica Estonica 54: 9-12. https://doi.org/10.12697/fce.2017.54.02

Motiejūnaite, J., Chesnokov, S. V., Czarnota, P., Gagarina, L. V., Frolov, I., Himelbrant, D., Konoreva, L. A., Kubiak, D., Kukwa, M., Moisejevs, R., Stepanchikova, I., Suija, A., Tagirdzhanova, G., Thell, A., \& Tsurykau, A. 2016. Ninety-one species of lichens and allied fungi new to Latvia with a list of additional records from Kurzeme. Herzo- 
gia 29(1): 143-163. https://doi.org/10.13158/ heia.29.1.2016.143

Motiejūnaite, J., Suija, A., Lõhmus, P., Kuznetsova, E., Tõrra, T., Progodina-Lukošiene, I. \& Piterāns, A. 2006. New or noteworthy lichens, lichenicolous and allied fungi found during the $16^{\text {th }}$ Symposium of mycologists and lichenologists in Latvia. Botanica Lithuanica 12(2): 113-119.

Muchnik, E., Wilk, K., Vondrák, J. \& Frolov, I. 2014. Contribution to the knowledge of the genus Caloplaca in Central European Russia. Polish Botanical Journal 59(2): 263-270. https://doi. org/10.2478/pbj-2014-0043

Nedospasova, G. V. 1983. Mosses and lichens of the Obdekh River valley. In: Vegetation cover of the Pskov Region and its protection. (In Russian). Leningrad. Pp. 44-53.

Nordin, A., Moberg, R., Tønsberg, T., Vitikainen, O., Dalsätt, Å., Myrdal, M., Snitting, D. \& Ekman, S. 2011. Santesson's Checklist of Fennoscandian Lichen-forming and Lichenicolous Fungi. Ver. April 29, 2011. http://130.238.83.220/santesson/ home.php (15 February 2018).

Notov, A. A., Himelbrant, D. E., Stepanchikova, I. S. \& Volkov, V. P. 2016. Lichens of Central Forest State Natural Biosphere Reserve. (In Russian). Tver. 332 pp.

Notov, A. A., Himelbrant, D. E. \& Urbanavichus, G. P. 2011. The list of lichens and allied fungi of Tver Region. (In Russian). Tver. 124 pp.

Protected areas of the Pskov Region. 2017. (In Russian). http:/ / priroda.pskov.ru/vidy-deyatelnosti/vidydeyatelnosti/ohrana-okruzhayushchey-sredy/ oopt-pskovskoy-oblasti (10 February 2018).

Pykälä, J. 2010. Additions to the lichen flora of Finland. V. Graphis Scripta 22: 54-62.

Randlane, T., Saag, A. \& Suija, A. 2016. Lichenized, lichenicolous and allied fungi of Estonia. Ver. December 31, 2016. http: / / esamba.bo.bg.ut.ee/ checklist/est/home.php (15 February 2018).

Savich, V. P. 1909. From the life of lichens of the south-western part of the Petersburg Province and the adjacent part of the Estland. (In Russian). Proceedings of St. Petersburg Society of Naturalists 40(2): 8-172.

Šoun, J., Vondrák, J., Søchting, U., Hrouzek, P., Khodosovtsev, A. \& Arup, U. 2011. Taxonomy and phylogeny of the Caloplaca cerina group in Europe. Lichenologist 43(2): 113-135. https:/ /doi. org/10.1017/S0024282910000721

Stepanchikova, I. S., Andreev, M. P., Himelbrant, D. E., Motiejūnaitė, J., Schiefelbein, U., Konoreva, L. A. \& Ahti, T. 2017. The lichens of Bolshoy Tuters Island (Tytärsaari), Leningrad Region, Russia. Folia Cryptogamica Estonica 54: 95-116. https:/ / doi.org/10.12697/fce.2017.54.14

Stepanchikova, I. S., Gagarina, L. V. \& Kataeva, O. A. 2013. New and rare lichens and allied fungi from the Novgorod Region, Russia. Folia Cryptogamica
Estonica 50: 49-55. http:/ /dx.doi.org/10.12697/ fce. 2013.50 .07

Stepanchikova, I. S., Himelbrant, D. E. \& Konoreva L. A. 2008. Lichens of Severo-Primorsky Park, Saint-Petersburg (in Russian). Vestnik SanktPetersburgskogo Gosudarstvennogo Universiteta, Biology series 3: 55-66.

Stepanchikova, I. S., Himelbrant, D. E. \& Konoreva, L. A. 2014. The lichens and allied fungi of the Gladyshevsky Protected Area (Saint Petersburg). Novitates Systematicae Plantarum Non Vascularium 48: 291-314.

Stepanchikova, I. S., Himelbrant, D. E., Kukwa, M. \& Kuznetsova, E. S. 2011a. New records of lichens and allied fungi from the Leningrad Region, Russia. II. Folia Cryptogamica Estonica 48: 85-94.

Stepanchikova, I. S., Himelbrant, D. E. \& Kuznetsova, E. S. 2010. Lichens of limestone outcrops on the Popovka River (Saint-Petersburg). (In Russian, English summary). Vestnik Tverskogo Gosudarstvennogo Universiteta, Biology and Ecology series 18(18): 118-128.

Stepanchikova I. S., Kuznetsova E. S. \& Himelbrant D. E. 2009. New records of lichens and allied fungi from the Eastern Leningrad Region. Folia Cryptogamica Estonica 46: 75-78.

Stepanchikova, I. S., Schiefelbein, U., Alexeeva, N. M., Ahti, T., Kukwa, M., Himelbrant, D. E. \& Pykälä, J. 2011b. Additions to the lichen biota of Berezovye Islands, Leningrad Region, Russia. Folia Cryptogamica Estonica 48: 95-106.

Tagirdzhanova, G. M., Kataeva, O. A. \& Stepanchikova, I. S. 2014. New lichen records from the Novgorod Region, Russia. Folia Cryptogamica Estonica 51: 103-107. https://doi.org/10.12697/ fce. 2014.51 .11

Tsurykau, A. 2017. New or otherwise interesting records of lichens and lichenicolous fungi from Belarus. III. With an updated checklist of lichenicolous fungi. Herzogia 30: 152-165. https://doi. org/10.13158/heia.30.1.2017.152

Tsurykau, A. \& Khramchenkova, V. 2011. Lichens from Gomel Region: a provisional checklist. Botanica Lithuanica 17(4): 157-163.

Urbanavichus, G., Gabibova, A. \& Ismailov, A. 2011. New records of lichens and lichenicolous fungi for Russia and the Caucasus. Turkish Journal of Botany 35: 291-297.

Wilk, K. 2012. Calcicolous species of the genus Caloplaca in the Polish Western Carpathians. Polish Botanical Studies 29: 1-91.

Wirth, V., Hauck, M. \& Schultz, M. 2013. Die Flechten Deutschlands. Band 1. 672 pp.

Yatsyna, A. P. 2013a. The lichens of manor parks in the central part of Minsk Region (Belarus). (In Russian). Novitates Systematicae Plantarum Non Vascularium 47: 302-309.

Yatsyna, A. P. 2014. Lichens from manor parks in Minsk region (Belarus). Botanica Lithuanica 20(2): 159-168. 
Yatsyna, A. P. 2013b. New species of lichens and nonlichenized saprobic fungi of NP "Braslav Lakes". (In Russian, English summary). Vesnik Vitebskaga Dziarzhaunaga Universiteta 2(74): 53-59.

Yatsyna, A. P. 2016. Lichen biota of some valid and proposed protected areas in Grodno Region (Belarus). (In Russian). Vesnik Hrodzenskaha Dziarzhaunaha Univesiteta Imia Ianki Kupaly. Seriya 5 2: 141-147.

Yatsyna, A. P. \& Merzhvinsky, L. M. 2012. Practical manual on lichens. (In Russian). Vitebsk. 224 pp.
Zhdanov, I. S. 2006. Saxicolous lichens of the Smolenskoe Poozerie National Park. In: Proceedings of the International conference "Lichen flora of Russia: state and perspective of exploration", St. Petersburg, October 24-27, 2006. (In Russian). St. Petersburg. Pp. 98-102.

Zhdanov, I. 2012. New and rare lichen records from the Central Siberian Biosphere Reserve (Krasnoyarsk Krai, Russia). II. Folia Cryptogamica Estonica 49: 83-87. 
32 Folia Cryptog. Estonica 